\title{
Services provided at the premarital counseling center and characteristics of the clients, in kayseri, Turkey
}

\author{
Mürüvvet Başer ${ }^{1 *},{\text { Tülay Özkan }{ }^{1}, \text { Pinar Tekinsoy }^{2}, \text { Evrim Albayrak}^{1} \text {, Sultan Taşci }}^{2}$ \\ ${ }^{1}$ University of Erciyes, Health Science Faculty, Department of Gynecology and Obstetric Nursing, Kayseri, Türkiye; ${ }^{*}$ Corresponding \\ author: mbaser_8@yahoo.com, tozkan@erciyes.edu.tr, evrim_albayrak@mynet.com \\ ${ }^{2}$ University of Erciyes, Health Science Faculty Dean of Assist, Department of Medical Nursing, Kayseri, Türkiye; ptekin- \\ soy@erciyes.edu.tr, sultantasc@yahoo.com.tr
}

Received 22 March 2011; revised 29 March 2011; accepted 10 April 2011.

\begin{abstract}
Objectives: The study was conducted retrospectively to evaluate the services offered at the Premarital Counseling Center (PCC) and the characteristics of the individuals who obtained counseling at the center in Kayseri. Methods: A retrospective review is based on data from the Premarital Counseling Center (PCC) in Kayseri. Seven hundred fifty four (754) individuals who attended the Center were included in the study sample. Data were collected from the Center's records. Records of all people were reviewed by the researchers. Differences in proportions were analyzed by Chi square test and test. Results: The age-average of the individuals who consulted the PCC was $26.2 \pm 8.3,91.1 \%$ of the individuals had Rh (+), $99.5 \%$ of them had VDRL $(-), 3.9 \%$ had $\mathrm{Hbs}$ Ag (+), $0.8 \%$ had HCV (+) while none of the individuals was HIV (+) affected. It's shown that $90.6 \%$ of the individuals who were between the ages of $15-19$ were women, $9.4 \%$ of them were men. The difference between the age and the gender of the individuals who came to the center was considered significant. It was determined that the individuals who received counseling services at the PCC were not given any kind of educational and consulting services before.
\end{abstract}

Keywords: Marriage; Premarital Counseling

\section{INTRODUCTION}

Family is an institution comprised of two individuals of opposite gender bound together legally and morally

This paper had been presented in 4.th International Congress of Reproductive Health \& Family Planning (April 20 - 23, 2005, Bilkent Hotel \& Conference Center, ANKARA, TÜRKIYE). and which has psychological, social, and biological functions [1]. Family is defined as a group or an organization while marriage is defined as a contract between two individuals of opposite gender who wish to live together, to share experiences, to have children, to raise them. Marriage is an institutionalized way, a system of relations, a kind of legal relationship that unites the husband and wife as spouses, that provides the children to be born with a given status in which the state has controls, rights and authority [2]. Various forms of marriage have existed for thousands of years all over the world though the significance and purposes may have varied. In our society, too, marriage is considered to be a normal and expected way of life.

Premarital Counseling Services (PCS), which are very common in developed countries, is a concept that has been discussed in Türkiye and in recent times efforts to establish such services have been tried in this country. PCS should begin in the form of engagement counseling services when choosing a spouse and later should provide information about such topics as family planning, genetic consultation, Rh incompatibility and sexuallytransmitted diseases [2]

Article 4721 of the Turkish Civil Code, which was legalized on $01 / 01 / 2002$, requires couples to obtain a health report that documents that the couples do not have any illnesses which would prevent them from marrying [3]. Besides, according to Article 122 of the 1593 Public Hygiene Code [4], men and women who intend to marry are required to undergo a medical examination before marriage. The 4134 circular of the Turkish Health Ministry declares that " $\ldots$ the consulting during the premarital period should be considered as an opportunity to provide consultancy services against infectious diseases and genetically infectious diseases and to provide the public with counseling services against the interpersonal risks, effects, prevention methods of the mentioned diseases." Health reports (which document that the couples 
do not have any illnesses that would prevent them from marrying) must be issued by State Clinics, Mother and Child Health Centers and Family Planning Centers. During the medical examination and counseling services husband and wife candidates must be questioned about syphilis, gonorrhea, soft chancre, leprosy, tuberculosis, mental diseases, AIDS, hepatitis A, hepatitis B and hepatitis $\mathrm{C}$ and genetically- transmitted diseases and must undergo a general medical examination. Services must provide the individuals with medical counseling and information concerning the aforementioned infectious diseases, genetically-transmitted diseases and family planning. Furthermore, the individuals must be informed about what to do if they believe they might have such diseases at a later time. If during the examination, the doctor suspects the presence of disease or if one of the future spouses asks the doctor to do certain medical tests, the required checks and tests can be done if paid by those making the request. The previously registered health reports must be evaluated only by medical institutes. In addition, in order to protect the dignity of the individuals involved and so as not to offend them, their human and personal rights must be respected [4]. Premarital Counseling Services should be organized and conducted according to the legal laws.

The study was conducted retrospectively to evaluate the services offered at the Premarital Counseling Center and the characteristics of the individuals who obtained counseling at the Kayseri Premarital Counseling Center (KPCC) of Kayseri Governorship in Kayseri Province.

\section{METHODS}

Study design: A retrospective, this research was carried out in Kayseri, Türkiye. Kayseri, one of the largest cities in Middle Anatolia, is a commercially and industrially developed city. This region of Türkiye comprises 16.917 square kilometers, making up $2.2 \%$ of Türkiye's land area.

KPCC of Kayseri Governorship has been providing services since November 2004. One nurse is on duty and provides individuals who come to the center for medical counseling with blood-grouping tests and such examinations as VDRL, HIV, HCV and HBS on request.

Data collection and Participants: This study is based on data from the KPCC in Kayseri. A total of 754 individuals who attend to the KPCC between the periods of three months were included in the study sample. There are registration records on file which indicate some characteristics of the individuals (who came to the Premarital Counseling Center), as well as age, gender, education and reports about the required medical examinations and tests, and medical reports of the doctors. We collected data from the Center's records on all clients.

The study was approved by Health Administration Organization in Kayseri.

Statistical analysis: Data were analyzed by using the Statistical Package Programmer. Data is expressed as means \pm standard deviation and percentages. Differences in proportions were analyzed by Chi square test and independent sample $t$ test. A $p$ value of $<0.05$ was considered as significant.

\section{RESULTS}

The characteristic features of the individuals who participated in the study are shown on Table 1. When we analyzed the data of the individuals who consulted the center, $50.7 \%$ of them were women and $49.3 \%$ of them were men. $62.9 \%$ of the individuals were between the ages of $20-29$. The average age of the women was 24.2 \pm 7.9 whereas the average age of the men was $28.3 \pm 8.2$ and the age-average was $26.2 \pm 8.3$. The difference between the age and the gender of the individuals who came to the center was considered significant $(p=0.000)$ (Table 2).

Table 1. Distribution of client's features of the premarital counseling center $(n=754)$.

\begin{tabular}{ccc}
\hline Descriptive Features & $\mathbf{n}$ & $\mathbf{\%}$ \\
\hline$\underline{\text { Gender }}$ & 382 & \\
Female & 372 & 50.7 \\
Male & & 49.3 \\
$\underline{\text { Age Groups }}$ & 128 & \\
$15-19$ & 231 & 17.3 \\
$20-24$ & 235 & 31.2 \\
$25-29$ & 74 & 31.7 \\
$30-34$ & 31 & 10.0 \\
$35-39$ & 42 & 4.2 \\
40 and older & & 5.7 \\
$\underline{\text { Age Average }(\mathbf{X} \pm \text { SD) }}$ & & \\
\hline
\end{tabular}

Table 2. Distribution client's genders of the premarital counseling center according to marriage average age $(n=754)$.

\begin{tabular}{ccccc}
\hline Gender & $\mathbf{n}$ & $\begin{array}{c}\text { Age Average } \\
(\mathbf{X} \pm \text { SD) }\end{array}$ & $\mathbf{t}$ & $\mathbf{p}$ \\
\hline Female & 376 & $24.2 \pm 7.9$ & -6.79 & $<0.001$ \\
Male & 365 & $28.3 \pm 8.2$ & & \\
\hline
\end{tabular}


The required tests and their results are listed on Table 3. Ninety one point one percent $(91.1 \%)$ of the individuals had Rh factor $(+), 99.5 \%$ of them had VDRL $(-)$, $3.9 \%$ had $\mathrm{Hbs} \mathrm{Ag}(+), 0.8 \%$ had $\mathrm{HCV}(+)$ while none of the individuals was HIV $(+)$ affected. Thirty one point three percent $(31.3 \%)$ of the individuals were tested to detect blood group, $28.0 \%$ of them had VDRL test, $17.1 \%$ had Hbs Ag test, 16.2\% had HCV test and 17.5\% had HIV test.

Table 4 shows the distribution of age groups and gender of the individuals. Thirty point nine percent $(30.9 \%)$ of the women were between the ages of $15-19$, whereas only $3.3 \%$ of the men were between $15-19$. Eighteen point six percent $(18.6 \%)$ of the $25-29$ age group were women whereas $45.2 \%$ of the age group were men $(\mathrm{p}<0.001)$.

No other educational or counseling services were given to the individuals but their questions were answered.

\section{DISCUSSION}

In Türkiye, marriage demographically is very important, because besides being prevalent throughout the country almost all birth occur within marriage. Therefore,

Table 3. Distribution of required medical test results of client's of the premarital counseling center $(n=754)$.

\begin{tabular}{|c|c|c|}
\hline Medical Test Results & n & $\%$ \\
\hline \multicolumn{3}{|l|}{$\underline{\operatorname{Rh}}$ Factor $(n=236)^{*}$} \\
\hline Positive & 215 & 91.1 \\
\hline Negative & 21 & 8.9 \\
\hline \multicolumn{3}{|l|}{$\underline{\operatorname{VDRL}}(\mathbf{n}=211) * *$} \\
\hline Positive & 1 & 0.5 \\
\hline Negative & 210 & 99.5 \\
\hline \multicolumn{3}{|l|}{$\underline{\text { HBs }(n=129) * *}$} \\
\hline Positive & 5 & 3.9 \\
\hline Negative & 124 & 96.1 \\
\hline \multicolumn{3}{|l|}{$\underline{\operatorname{HCV}(n=122)^{* *}}$} \\
\hline Positive & 1 & 0.8 \\
\hline Negative & 121 & 99.2 \\
\hline \multicolumn{3}{|l|}{$\underline{\operatorname{HIV}(n=131)^{* *}}$} \\
\hline Positive & - & - \\
\hline Negative & 131 & 100.0 \\
\hline
\end{tabular}

*Blood groups had been tested unknown persons. ** This test had been alone payment and voluntary.
Table 4. Distribution client's age groups of the premarital counseling center according to gender $(n=754)$.

\begin{tabular}{cccccccc}
\hline \multirow{2}{*}{$\begin{array}{c}\text { Age } \\
\text { Groups }\end{array}$} & \multicolumn{9}{c}{ Female } & \multicolumn{2}{c}{ Male } & $\mathbf{X}^{2}$ & $\mathbf{p}$ \\
\cline { 2 - 5 } \cline { 2 - 5 } & $\mathbf{n}$ & $\mathbf{\%}$ & $\mathbf{n}$ & $\mathbf{\%}$ & & \\
\hline $15-19$ & 116 & 30.9 & 12 & 3.3 & & \\
$20-24$ & 131 & 34.8 & 100 & 27.4 & & \\
$25-29$ & 70 & 18.6 & 165 & 45.2 & & \\
$30-34$ & 30 & 8.0 & 44 & 12.1 & 132.683 & $<0.001$ \\
$35-39$ & 12 & 3.2 & 19 & 5.2 & & \\
40 and older & 17 & 4.5 & 25 & 6.8 & & \\
Total & $\mathbf{3 7 6}^{*}$ & $\mathbf{1 0 0 . 0}$ & $\mathbf{3 6 5} \mathbf{F}^{* *}$ & $\mathbf{1 0 0 . 0}$ & \\
\hline
\end{tabular}

*6 clients no data. ** 7 clients no data.

age at first marriage is a significant demographic indicator since it represents the onset of a women's exposure to the risk of pregnancy. The median age at first marriage is 20.8 among women $25-49$, indicating that half of the women in those age groups married before that age. A steady increase is observed in the median age at first marriage, from years for the $45-49$ age groups to 22 years for the $25-29$ age groups. There has been a marked decline in getting married at very young ages. [5].

In our study, there was significant difference between the genders concerning first marriage average age $(p=$ 0.000 ). $30.9 \%$ of the women married at ages $15-19$, whereas only $3.3 \%$ of the men were in the $15-19$ age groups. The 25 - 29 age group was composed of mostly men whereas a small portion of the same age group consisted of women $(p=0.001)$ (Table 3). We know that adolescent marriages may result in adolescent pregnancy in Türkiye. In our study, it was found that a large number of women were married between the ages of $15-24$. Teenage fertility is a major health concern because teenage mothers and their children are at high risk of illness and death [6-8].

It has been stated that a large portion of the men married between the ages of $20-29$. In Türkiye, the family responsibility is mostly on men's shoulders. Therefore, without sustainable, stable employment and completion of the military service, marriage does not happen. Also, in Turkish culture, when marriage occurs, it is preferred that the women be younger than the men. Considering the results obtained, it may be concluded that early marriage is more common among the women compared to the men in Kayseri.

Both in Türkiye and in the world $\mathrm{ABO}$ and Rh systems are used commonly for blood grouping. It is very 
important for a baby's health if the mother's Rh factor is negative. Each Rh $(+)$ baby of mothers with $\mathrm{Rh}(-)$ may be at risk for erythroblastosis fetalis $[9,10]$. Thus, Rh factor must be determined before the preparations for a woman's pregnancy period. In this study, $91.1 \%$ of the individuals were $\mathrm{Rh}(+)$ factor. According to another study [11], $90.7 \%$ of the subjects were $\mathrm{Rh}(+)$, and this result was similar to ours. The frequency of venereal diseases and HIV/AIDS has increased recently. According to the reports of the World Health Organization, it is emphasized that more than 6 million people are HIV/AIDS infected and urgently need medical treatment [12-14]. By December 2001, 40 million HIV/AIDS cases and 20 million HIV/AIDS death were reported all over the world. In Middle Africa, the number of HIV/AIDS cases is reported to be increasing so fast as to change the population pyramids [15]. According to the Health Ministry data (2008), in Türkiye only one HIV/AIDS case and only one carrier were reported in 1985 while the number of HIV/AIDS cases and porter increased to3175 according to the Ministry's 2008 data. 682 of the cases were AIDS, 2493 of them were HIV positive [16].

HIV/AIDS cases in Türkiye are mostly seen in the 15 - 49 age groups and $68.8 \%$ of the cases were men, $31.2 \%$ were women [17]. It was positive and encouraging not to have seen HIV $(+)$ cases in our study (Table 2 ).

Reproduction is considered normal within marriage in our country. Therefore, it is very important for the couples to have protection against venereal diseases, to be diagnosed and to receive treatment in case they are infected. Today, there are more than 50 venereal diseases and many other genitourinary infections that can affect pregnancy [18]. In our study, it was found that $99.5 \%$ of the individuals who participated in the study had VDRL $(-), 3.9 \%$ had Hbs Ag (+), 0.8\% had HCV (+) (Table 2). Another study carried out on the same subject matter showed similar results that $3.6 \%$ of the individuals who wanted a health report before marriage had $\mathrm{Hbs} \mathrm{Ag}(+)$ [19].

In this study, it was discovered that the number of the tests conducted was very small compared to the individuals who had counseling. This is due to the fact that the tests are carried out on request and must be paid for.

According to the data obtained from this study, we realize that there are some differences between the law and practice, that is, the realities of what is actually carried out.

- The Türkiye Republic Health Ministry circulars declare that "...marriage applications considered as an opportunity" and 123 and 124 articles of Public Hygiene Code's declaration that "... the VDRL, HBS, HCS, and HIV tests should be conducted on only those who can pay for these services and who wish these tests..."

- The Türkiye Republic Health Ministry circulars considers the marriage applications as an opportunity to give the individuals about to marry counseling concerning reproductive health whereas there is not any regular, organized education and consultancy for them except the questions directed to them.

\section{CONCLUSIONS}

In light of our results, it is recommended that couples who receive counseling services at the premarital counseling centers should be given not only psychological counseling but also family planning information, genetic counseling, blood compatibility tests, as well as information about sexually transmitted diseases. Furthermore, all of these services and information should be provided by health professional.

\section{REFERENCES}

[1] Özgüven, E.Ö. (2001) Ailede iletişim ve yaşam. Psikolojik Danışma Rehberlik Eğitim Merkezi Yayını, Ankara.

[2] Özgüven, E.Ö. (2000) Evlilik ve aile terapisi. Deprem Yayınları, Ankara.

[3] Türk Medeni Kanunu. Kanun No: 4721. Kabul Tarihi: 22.11.2001. Resmi Gazete. Yayım Tarihi: 08.12.2001. Say1: 24607. Yürürlülük Tarihi: 01.01.2002.

[4] İstanbul tabip odası pratisyen hekim komisyonu "evlilik raporlar1" toplant1 raporu (2002)

http://www.istabip.org.tr/ph/ev rapor.asp. Accessed September 17, 2005.

[5] Hacettepe University Institute of Population Studies (2009) Turkey demographic and health survey, 2008. Population and Health Research of Turkey, Hacettepe University Institute of Population Studies, Ministry of Health General Directorate of Mother and Child Health and Family Planning, State Planning Organization and European Union. Ankara, Turkey.

[6] Karadağ, N., Aslantekin, F. (2005) Balıkesir merkez 2 No'lu sağlık ocağı bölgesindeki 15-49 yaş kadınlarda aile planlaması hizmetlerinin ve yöntemlerinin kullanırlılığı. Hemşirelik Forumu. Ocak-Şubat: 50-53.

[7] Başer, M. (2003) Adölesan annelik ve hemşirelik yaklaşımları. Hemşirelik Forumu. 6 (3): 40-43.

[8] Başer, M. (2000) Adölesan cinselliği ve gebelik. Cumhuriyet Üniversitesi Hemşirelik Yüksekokulu Dergisi. 4 (1): 50-54.

[9] Taşkın, L. (2007) Doğum ve kadın sağlığı hemşireliği. Sistem Ofset Matbaacılık, Ankara.

[10] Çavuşoğlu, H. (2008) Çocuk sağlı̆̆ı hemşireliği. Genişletilmiş 8. Baskı. I. Cilt. Sistem Ofset Matbaacılık, Ankara.

[11] Zerin, M., Karakılçık, A., Z., Nazlıül, Y. (2004) Şanlıurfa bölgesinde $\mathrm{ABO}$ ve $\mathrm{Rh}$ kan gruplarının 
dağılımı. Harran Tıp Fakültesi Dergisi. 1: 3.

[12] WHO (2004) '3x5' Progress report. World Health Organization.

[13] Centers for Diseases Control and Prevention (2003) Increases HIV diagnosis -29 states 1999-2002. MMWR. 53: $1145-48$

[14] del Rio, C. (2005) AIDS. The Second Wave. Archives of Medical Research. 36: 682-88.

[15] Özcebe, H., Akın, A. (2003) Gender inequality and male participation in the reproductive health. $3^{\text {rd }}$ International Reproductive Health and Family Planning Congress, Bayt ltd.ști, Ankara.

[16] Ministry of Health Republic of Türkiye HIV/AIDS Data Tables 1985- 2008 (2008) http://www.erdemlidh.gov.tr/dosyalar/hiv\%20aids\%20ve ri\%20tablolar\%C4\%B1.pdf. Accessed March 22, 2011.

[17] Tümer, A. (2005) HIV/AIDS Epidemiyolojisi ve korunma. Available at:

http://www.hatam.hacettepe.edu.tr/. Accessed September 8, 2005.

[18] Gilbert, E.S., Harmon, J.S. (2002) Yüksek riskli gebelik ve doğum. In: Taşkın L. (eds) Palme Yayıncılık, Ankara.

[19] Tosun, S., Yücetürk, M., Türkel, N., Saruç, M., Yüceyar, H. (2003) Evlilik öncesi tetkik sonucu hepatit B taşıyıcılığı saptanan kişilerin eşlerinin hızlı immünizasyonu. I. Temel 2003 sağllk hizmetleri sempozyumu 'birinci basamakta yeni yaklaşımlar' özet kitabı. Manisa. 